\title{
Composition and structure of mud volcanic deposits in Lake Baikal: the Class@Baikal Project data report
}

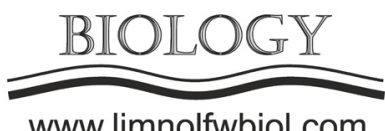

www.limnolfwbiol.com

\author{
Kudaeva A.A. ${ }^{1}{ }^{*}$, Kudaev A.A. ${ }^{1}$, Akhmanov G.G. ${ }^{1}$, Vidischeva O.N. ${ }^{1}$, Solovyeva M.A. ${ }^{1}$, \\ Khlystov O.M. ${ }^{2}$
}

${ }^{1}$ Geology Faculty, Lomonosov Moscow State University, Leninskiye Gory, 1, Moscow, 119234, Russia

${ }^{2}$ Limnological Institute, Siberian Branch of the Russian Academy of Sciences, Ulan-Batorskaya Str., 3, Irkutsk, 664033, Russia

\begin{abstract}
The Lake Baikal sedimentary basin is characterized by a presence of oil and gas seepages. Oligocene-Miocene oil-and-gas source rocks are inferred for the basin. It can be assumed that the study of deposits of mud volcanoes (mud breccia) of Lake Baikal may indicate the roots of mud volcanoes (MVs), which should correspond to oil and gas source rocks, as it works in classical examples of mud volcanoes. Study of mud breccia of Lake Baikal shows that MVs roots are much shallower in sedimentary section than a potential source of hydrocarbons. In addition, the results of these studies are consistent and supplement with existing ideas about a mechanism of the Lake Baikal mud volcanoes. Understanding of the Lake Baikal mud volcanoes will allow getting more precise idea of both the structure of the sedimentary strata of the lake and phenomenon of mud volcanism in general.
\end{abstract}

Keywords: mud volcanism, mud breccia, gas hydrates.

\section{Introduction}

Mud volcanoes (MVs) are surface expressions of focused fluid flow inside hydrocarbon-bearing sedimentary basins. They are a specific category of hydrocarbon seeps, connected hydraulically to petroleum (natural gas and oil) rich sediments and accumulations, which may or may not have commercial importance (Mazzini and Etiope, 2017).

The first mud volcanoes of the Lake Baikal were discovered at the beginning of the XXI century. Then, some mud volcanoes in Lake Baikal were investigated during the Class@Baikal annual expeditions (2014 2019). The main aim of the studying of these objects was searching of the hydrocarbon source activity. We took some analyses of mud breccia composition to distinguish nature of the breccia material.

\section{Materials and Methods}

There are four mud volcano areas in the Lake Baikal: "Ol'khonskiye vorota", "Posol'skaya bank", "Kukuyskaya ridge" and "Academic Ridge". We observed two mud volcanoes from "Posol'skaya bank" area ("Bolshoy" and "Malen'kiy") and two volcanoes from "Olkhonskiye vorota" area ("Novosibirsk" and "Saint-Petersburg").

We shot seismic profiles. All of the objects are characterized by a presence of the acoustic void in sediments below the mounts and by presence of faults in base of the structure. Other studies consisted of bottom sampling. Sedimentologicaly, deposits of mud volcanoes are characterized by intervals of breccia in association with gas hydrates. Geochemically, hydrocarbon gases from gas hydrates and dissolved gases in sediment nearby the mud volcano crater presented predominantly by methane and $1-2 \%$ of homologues; carbon isotopic ratio indicates the thermogenic origin of the gas.

Laboratory analyses of mud volcanic breccia included X-ray diffraction of the clay minerals in samples and grain size analyses. We choose only clay minerals to compare. So, we compared material which can accumulated evenly across the lake in different geological times.

\section{Results}

We compared grain size and mineral composition between the different stations within each volcano, between different volcanoes within each mud volcano area, between two mud volcano areas.

- According to grain size and mineral analyzes, it was found that:

- The composition of the breccia matrix is different from the composition of the breccia rock fragments;

- Mud volcanic breccia of two structures of the "Ol'khonskiye vorota" area have a similar mineral

*Corresponding author.

E-mail address: chuuudoo@yandex.ru (A.A. Kudaeva)

(C) Author(s) 2020. This work is distributed under the Creative Commons Attribution 4.0 License. 
composition;

- Mud volcanic breccia of two structures of the "Posol'skaya bank" area have a significantly different mineral composition;

- Mud volcanic deposits of two areas of mud volcanism of Lake Baikal have a different composition;

- Modern hemipelagic deposits of Lake Baikal differ in mineral composition from deposits of mud volcanoes.

Beside them, we were compared our results with (Khlystov et al., 2019) existing ideas about mud volcanism in the area of the Academic ridge mud volcanoes complex and we believe that the mud volcanoes of other areas have a similar origin.

\section{Conclusions}

Lake Baikal is a young sedimentary basin with a thick sedimentary stratum, and it is characterized by the development of mud volcanoes. However, the Baikal mud volcanoes differ from the classical ones. Their roots are located much more above the oil and gas source strata, at shallow depths and are associated with gas hydrate deposits.

Thus, in the formation of mud volcanoes of Lake Baikal there are next main factors: (1) - fluids migrating from greater than the source depths, playing the role of a thermal agent; (2) - conducting faults (neotectonics); (3) - accumulations of subaquatic gas hydrates. It can be assumed that a quantitative increase in each of them can lead to the formation of a focus of a mud volcano. Despite the uniqueness of the mud volcanoes of Lake Baikal due to the shallow occurrence of their roots, this phenomenon remains a sign of activity of the hydrocarbon system of the sedimentary strata of Lake Baikal.

\section{References}

Mazzini A., Etiope G. 2017. Mud volcanism: an updated review. Earth-Science Reviews 168: 81-112. DOI: 10.1016/j. earscirev.2017.03.001

Khlystov O.M., Poort J., Mazzini A. et al. 2019. Shallow-rooted mud volcanism in Lake Baikal. Marine and Petroleum Geology 102: 580-589. DOI: 10.1016/j. marpetgeo.2019.01.005 